一事例報告一

根管治療器具の破折片および根管充填剤の漏出に関連する歯槽骨吸収像の形態が 身元確認に有用であった一事例

伊澤 光 ${ }^{1}$, 古川 明 ${ }^{2}$, 丸山 澄 3,4 , 堤 博文 $^{3,4}$, 小室歳信 3,4

1昭和大学歯学部スペシャルニーズロ腔医学講座口腔衛生学部門

干142-8555 東京都品川区旗の台 1-5-8

2 青森県警察協力歯科医会

干030-0811 青森県青森市青柳 1-3-11

3 日本大学歯学部法医学講座

干101-8310＼cjkstart東京都千代田区神田駿河台 1-8

${ }^{4}$ 日本大学総合歯学研究所社会医学研究部門

干101-8310 東京都千代田区神田駿河台 1-8

\title{
A case of personal identification based on the radiographic image of a remnant of a broken endodontic instrument and alveolar bone resorption
}

\author{
Hikaru Izawa1, Akira Furukawa², Sayaka Maruyama ${ }^{3,4}$, \\ Hirofumi Tsutsumi ${ }^{3,4}$ and Toshinobu Komuro ${ }^{3,4}$ \\ ${ }^{1}$ Department of Special Needs Dentistry, Division of Hygiene and Oral Health, \\ Showa University School of Dentistry \\ 1-5-8, Hatanodai, Shinagawa-ku, Tokyo 142-8555, Japan \\ ${ }^{2}$ Forensic Dental Examiner Association for Aomori \\ 1-3-11, Aoyagi, Aomori 030-0811, Japan \\ ${ }^{3}$ Department of Legal Medicine, Nihon University School of Dentistry \\ 101-8310, Kanda-Surugadai, Chiyoda-ku, Tokyo 101-8310, Japan \\ ${ }^{4}$ Devision of Social Dentistry, Nihon University School of Dentistry \\ 101-8310, Kanda-Surugadai, Chiyoda-ku, Tokyo 101-8310, Japan
}

(Received 17 April 2018; accepted 4 July 2018;

Published online 30 August 2018 in J-STAGE DOI: 10.3408/jafst.749)

We experienced a case of successful identification of an unknown body found at breakwater based on root canal treatment. After matching the dental findings of the body to the treatment history of individual's dental records, 23 teeth showed agreement in findings. Although 8 teeth did not agree in findings, they were consistent in terms of dental treatment history. There was inconsistency in the remaining tooth. This tooth was determined as intact, but the dental records indicated the existence of a resin composite restoration on that tooth. However, that inconsistency never became a critical determinant factor. Comparison of periapical radiographs of the 
body with the dental records revealed that the right mandibular first premolar teeth showed considerable similarity to the images of a broken endodontic instrument and a alveolar bone resorption caused by the leakage of root canal sealer at the middle of the root. Given the above information, we concluded that the identification as the same individual is reasonable. It was thought that a case where the findings of a dental medical accident helped to confirm the identity was unusual.

Key words: Personal identification, Dental finding, Instrument fracture, Traumatic perforation, Alveolar bone resorption

\section{緒 言}

歯科所見は終生不変とは言えないが，治療方法や 修復のための歯科材料は多様性に富み, さらには金 属やレジン系などの材料は物理化学的侵襲に強く保 存性に優れていることから，死後間もない死体はも とよりむしろ高度に腐敗したおよび白骨化した死体 の個人識別においてきわめて有用である11. また， 根管充填の施された歯については，補綴修復物のほ かに根管拡大，根管充填抢よび支台の状況について エックス線写真上で判断することが可能であり, 個 人識別のためにはより多くの情報を得ることができ $ろ^{2,3)}$.

歯髄炎や歯根膜炎の治療に際し, 根管治療器具を 用いて根管拡大および根管充填処置を行う場合, 根 管壁への穿孔抢よびそれに伴う根管充填剂の漏出あ るいは治療器具が破折しその破折片が残存すること は稀にある。

今回，根管充填剤の漏出に関連すると思われる歯 槽骨吸収および根管治療器具と思われる根管内異物 の形態により身元確認された事例を経験した. 文献 検索した範囲ではこのような事例の報告例は見あた らなかったので，ここに報告する.

\section{事例経過}

\section{1 事例の概要}

ある漁師が出漁の準備中，防波堤付近で人様のも のが浮いているのを発見した。しかし，その辺りは 普段から小動物の死骸が浮いていることがあったた め，あまり気にせず出港した，漁を終え帰港した 際，今朝方に見たものが気になり確かめてみたとこ ろ，黒っぽい服を着た人が仰向けで浮いていたの
で，通報した。海上保安庁職員と救急隊員が引き揚 げ救出したが，すでに心肺停止状態であった．死体 に他為的損傷はないが，殺害され海に遺棄された可 能性を払拭できないことから，司法解剖に付された 後，歯科所見から身元確認が依頼された。

\section{2 検査所見および照合}

1）歯科所見 (肉眼所見)

\section{(1) 死体}

身元不明死体の口腔内写真（Fig. 1）抢よび口内 法エックス線写真（以下，デンタル写真. Fig. 2 : 身元不明死体）を参考とし，Fig. 3 に示すように， 死後 (身元不明死体) の歯型図 (デンタルチャート) を作成した。なお，死後のデンタル写真は，Venus Dental X-ray（Yoshida Seiko Co-LTD，1980年製） を用い, $100 \mathrm{v}, 10 \mathrm{~mA}$ および照射時間 1 秒の条件 で撮影した。

【上顎】左側の中切歯 · 側切歯 ·第三大臼歯は健 全歯であり，犬歯にはレジン充填（resin filling， RF，遠心隣接面から尖頭を含まずに口蓋側面，す なわち遠心隣接面口蓋側面 disto-palatal surface （DP）に及ぶ充填）および前歯部には楔状欠損が認 められた。 また，第一・第二小臼歯には全部金属冠 （full metal crown，FMC，金属による全部修復， 銀色)，第一大臼歯にはインレー（inlay，In，近心 隣接面から近心煩舌側咬頭を含まずに咬合面，すな わち近心隣接面咬合面 mesio-occulusal surface （MO）に及ぶ金属による部分修復，銀色）が装着 され，第二大臼歯にはアマルガム充填（amalgam filling, AF, 咬合面occulusal surface（O）にのみ 充填）が確認された.

一方，右側の中切歯では遠心隅角を含む先端部で 歯冠が破折しているが，処置の形跡は見あたらず， 


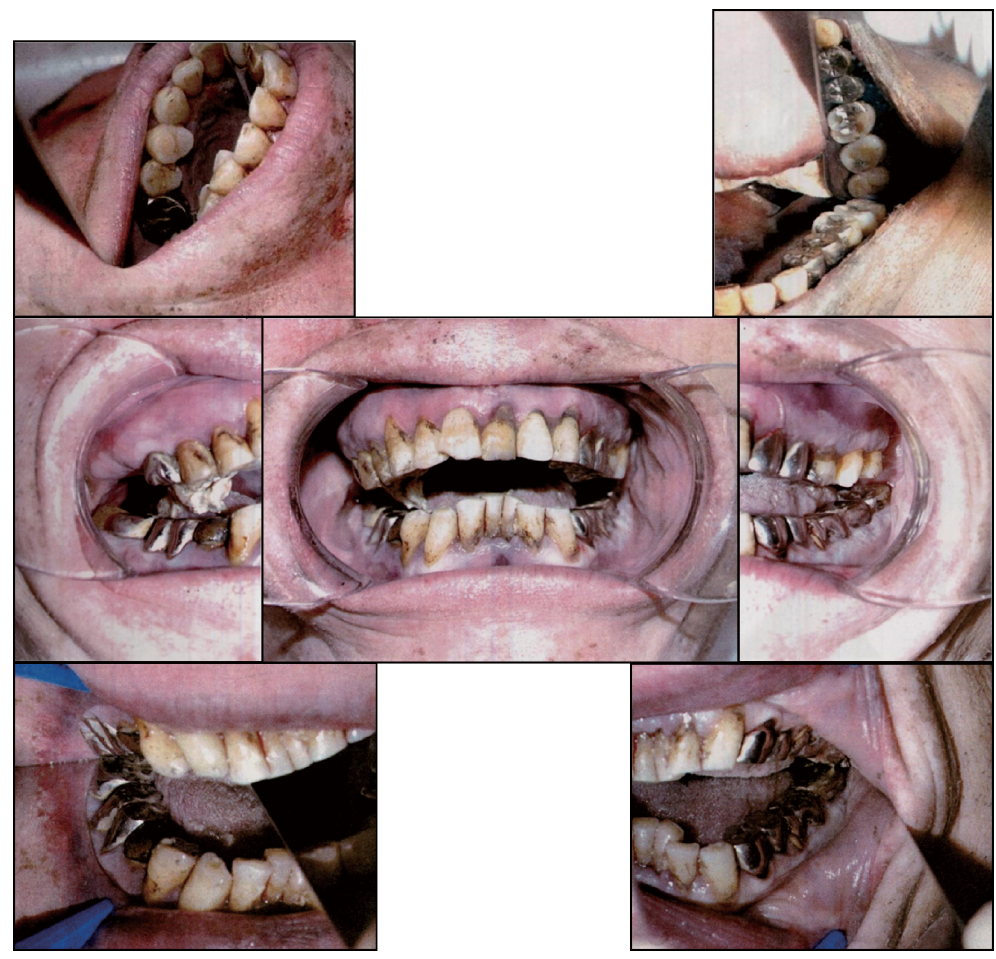

Fig. 1 Oral photographs of the unidentified body

The occlusal views of maxillary and mandibular dentition flipped after using a mirror.

側切歯は健全歯であり，犬歯および第一小臼歯には RF（いずれも㚘側面 buccal surface（B）にの久充 填）が認められた（ただし，犬歯は健全歯の可能性 もある)。をた，第二小臼歯ではう蝕第二度 $\left(\mathrm{C}_{2}\right.$, MO にわたり象牙質内に止まるう蝕)，第一大臼歯 では FMCが装着された。第二・第三大扫歯では欠 損 $(\times)$ し，歯槽窩は認められなかった.

【下顎】左側の中切歯には RF（B）が認められ， 側切歯と犬歯は健全歯であった。第一・第二小臼歯 と第一・第二大臼歯には FMC (銀色), 第三大臼 歯にはIn（MO，銀色）が装着されていた.

一方，右側の中切歯には RF（B)，側切歯と犬歯 では健全歯（側切歯には楔状欠損あり）であった。 第一小臼歯と第三大臼歯には In（いずれも遠心隣 接面から遠心煩舌側咬頭を含まずに咬合面 distoocculusal surface（DO）に及ぶ金属による部分修 復，銀色）が装着されていた。第三大臼歯はIn と 記したが，開口量が不十分なために確認が困難であ り, AF の可能性もある. 第二小臼歯と第一 · 第二 大臼歯には FMC (銀色) が装着されていた。

\section{(2) 該当者}

入手した該当者の歯科診療録およびデンタル写真 3 枚（Fig. 2: 該当者）をもとに該当者の生前のデ ンタルチャート（Fig. 3 : 該当者）を作成した。な お，入手した歯科診療録は死亡のおよそ一月前に受 診したものであった。

【上顎】左側の中切歯には RF（充填面不明），側 切歯と第三大臼歯は健全歯, 犬歯には RF（遠心隣 接面から尖頭を含まずに㚘側面（唇面ともいう）, すなわち遠心隣接面规側面 disto-buccal surface (DB) ), 第一・第二小臼歯には FMC，第一大臼歯 には In（MO）とRF（DO）および第二大臼歯に は $\mathrm{AF} （ \mathrm{O} ）$ が確認された。

一方，右側では中切歯には歯冠破折（部位不明） が存在し，側切歯· 犬歯・第一小臼歯は健全歯であ り, 第二小臼歯は $\mathrm{C}_{2}$, 第一大臼歯は $\mathrm{FMC}$ および 第二・第三大臼歯は欠損していた.

【下顎】左側では中・側切歯抢よび犬歯が健全歯 であり，第一・第二小臼歯と第一・第二大臼歯には FMC 抢よび第三大臼歯には In（MO）が装着され 


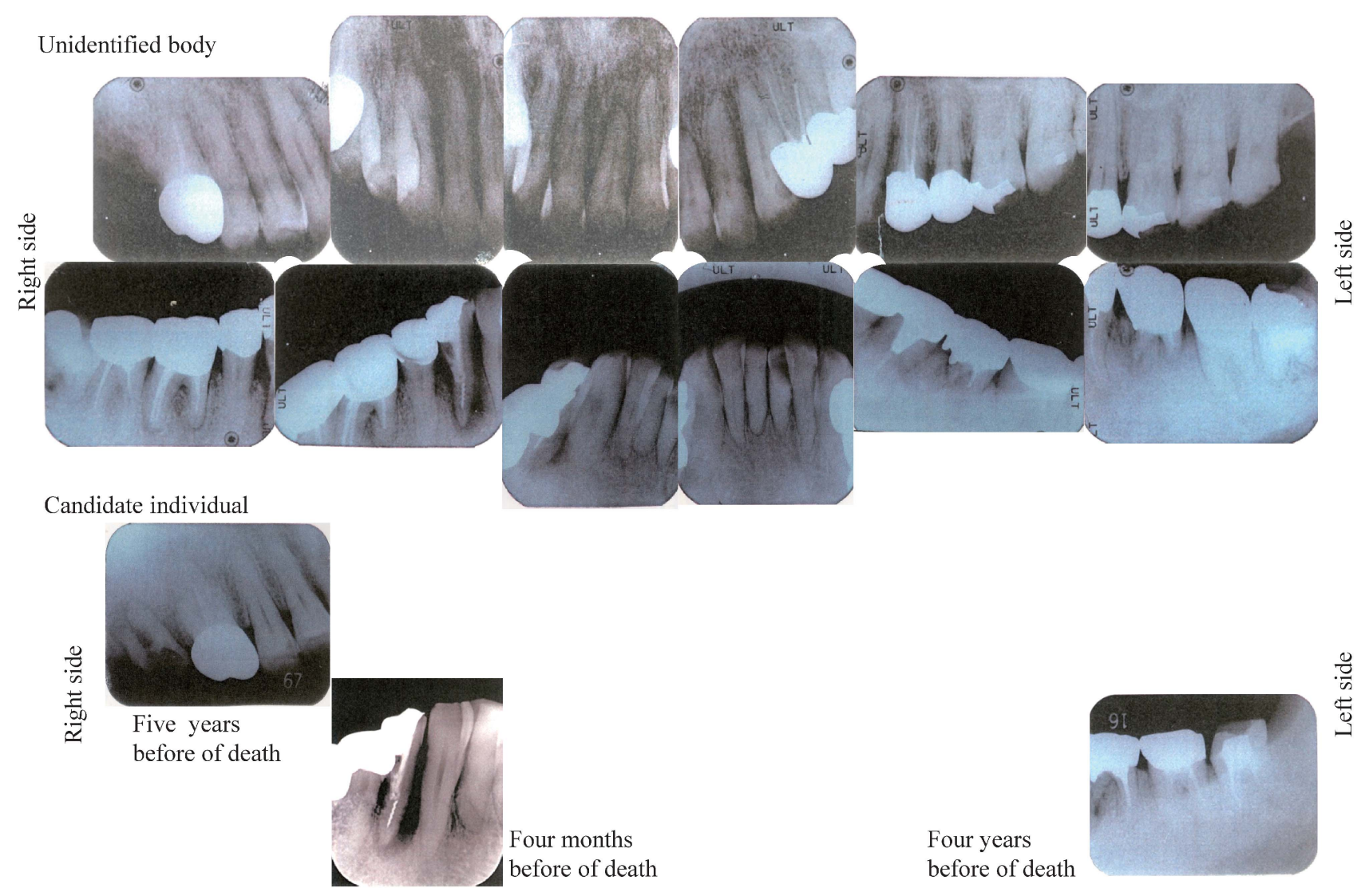

Fig. 2 Intraoral radiographs of the unidentified body and the candidate individual.

ていた.

一方，右側では中・側切歯と犬歯が健全歯であ り，第一小臼歯には In（DO）および第二小臼歯と 第一・第二大臼歯には FMC が装着されていた。 た，第三大臼歯には AF（おそらくO）が確認され た。

2）エックス線所見

(1) 死体

残存歯およびその周辺部についてデンタル写真撮 影を行った（Fig. 2-身元不明死体）.

【上顎】残存歯は前歯部，左側の第一・第二小臼 歯と第一・第二・第三大臼歯抢よび右側の第一・第 二小臼歯と第一大臼歯，計14歯であった．右側の第 二・第三大臼歯は欠損し，明確な歯槽窩は認められ なかった。

左側では第一・第二小臼歯には歯冠部すべてを覆 うような，また第一大臼歯には歯冠部の一部を覆う ようなエックス線不透過像（金属と思われる）が認
められた．第一小臼歯は歯髄処置が施され，2 根管 で，根管充填剂（材）と思われるエックス線不透過 像が認められた．犬歯の歯冠部遠心側には半米粒大 のエックス線透過像（う蝕あるいはレジン充填と思 われる）が認められた。側切歯の歯根尖部は遠心へ わずかに弯曲していた。

一方，右側では第一大臼歯には歯冠部すべてを覆 うようなエックス線不透過像（金属と思われる）が 認められた。 また歯髄処置が施され，口蓋根でエッ クス線不透過像（根管充填剂（材）と思われる）が 認められた。

なお，上顎残存歯の歯根尖において根尖病巣など の異常所見は認められなかった。

歯槽骨は全歯にわたって歯根長の $1 / 3$ に及ぶ水平 的骨吸収像が認められ，軽度〜中等度の歯周疾患に 罹患していることが推測された.

【下顎】残存歯は前歯部，左右側の第一・第二小 臼歯および第一・第二・第三大臼歯，計16歯であっ 

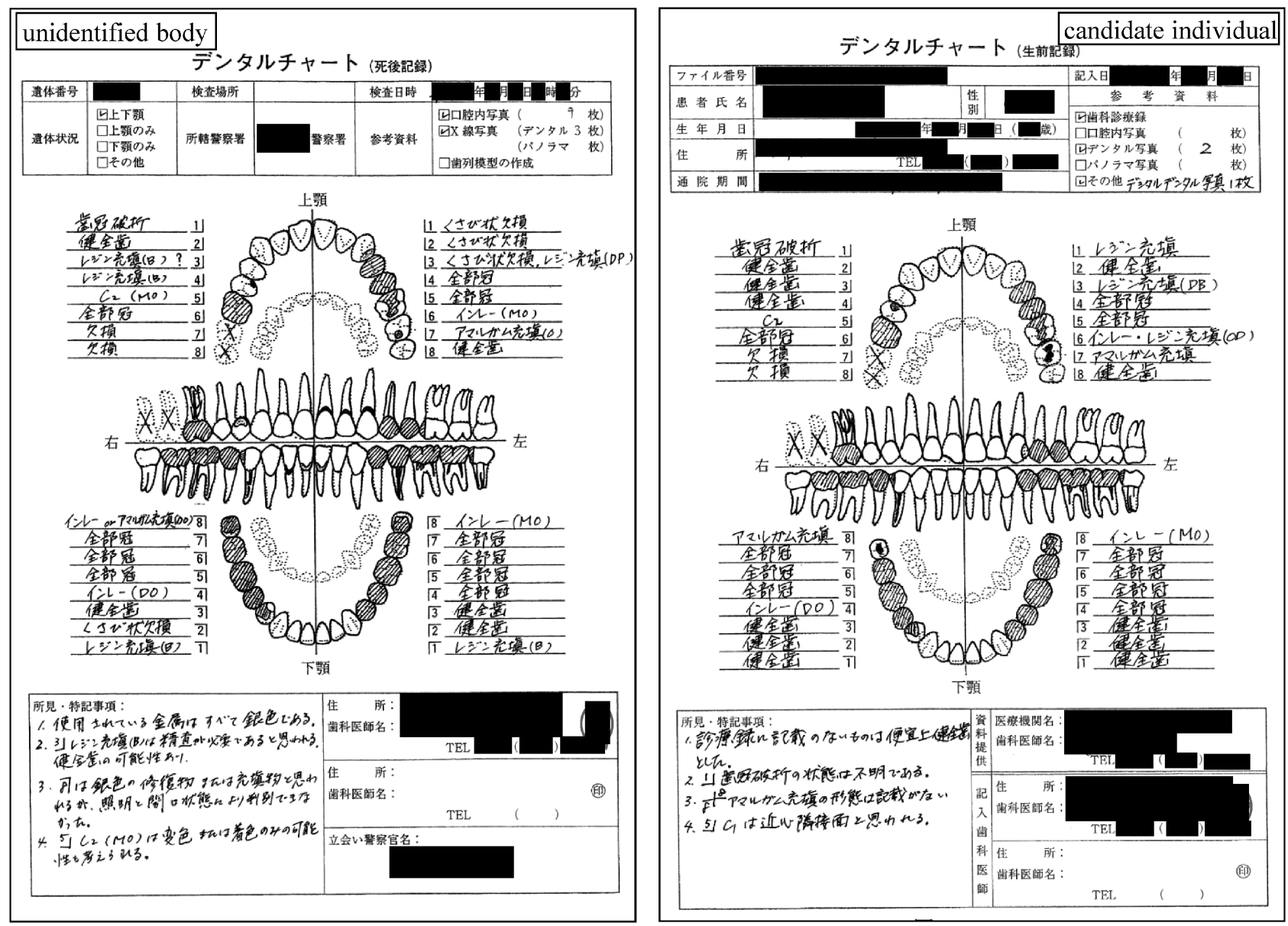

Fig. 3 Odontograms of the unidentified body and candidate individual.

た。

左側では第一・第二小臼歯と第一・第二大臼歯に は歯冠部すべてを覆うような，また第三大臼歯には 歯冠部の一部を覆うようなエックス線不透過像（金 属と思われる）が認められた。第二小臼歯と第一。 第二・第三大臼歯は歯髄処置が施され，前者は 1 根 管で，後三者は近心・遠心根管でエックス線不透過 像（根管充填剤（材）と思われる）が認められた. 第一大臼歯の歯根尖では根尖病巣が認められた。中 切歯は歯冠部においてほぼ歯冠大のエックス線透過 像（う蝕あるいはレジン充填と思われる）が認めら れた。

一方，右側では第一小臼歯と第三大臼歯には歯冠 部の一部を覆うようなエックス線不透過像が認めら れた。 また第二小臼歯と第一・第二大臼歯には歯冠 部すべてを覆うようなエックス線不透過像が認めら
れた. 第一小臼歯と第一・第二大臼歯では歯䯣処置 が施され, 前者は 1 根管で, 後二者は近心・遠心根 管でエックス線不透過像（根管充填剂（材）と思わ れる）が認められた。 とくに，第一小臼歯では歯根 長の $1 / 4$ 程度までは根管充填材と, 歯根長の $1 / 2$ ま では根管充填剂と思われるエックス線不透過像,さ らには歯根長 $1 / 2$ から $3 / 4$ までは螺旋形のエックス 線不透過像（根管治療器具の破折片と思われる）が 認められた．第一小臼歯の歯根尖ではほぼ歯冠大 の, また右側第一大臼歯のそれでは米粒大の根尖病 巣が認められた。

歯槽骨は左側第一大臼歯部では歯根長の $1 / 2$ 程 度, 左側小臼歯部および右側第二小臼歯と第一大臼 歯では歯根長の $1 / 3 \sim 1 / 2$ 程度の水平的骨吸收像が 認められた. 右側第一小臼歯では歯根尖部まで垂直 的骨吸収像が認められた。 


\section{(2) 該当者}

入手したエックス線写真は, Fig. 2 : 該当者に示 すと抢り, 右側上顎臼歯部 (Five years before of death), 左側下顎大臼歯部 (Four years before of death）および右側下顎側切歯一犬歯一第一 - 第二 小臼歯（Four months before of death）を撮影した デンタル写真であった。

【右側上顎臼歯部】第一小臼歯は健全歯であり， 第二小臼歯は歯冠部の近心に半米粒大のエックス線 透過像が認められた。第一大臼歯は歯冠部を覆うエ ックス線不透過像（金属と思われる）が認められ， その口蓋根に掞いて歯根長の $1 / 2$ 程度までのエック 又線不透過像（根管充填剤（材））が認められた。 第二大臼歯は, 残根 $\left(\mathrm{C}_{4}\right)$ を呈し, 煩側根は根間 中隔が崩壊し, 近心根と遠心根に分離していた。

【左側下顎大臼歯部】第一・第二大曰歯は歯冠部 を覆うエックス線不透過像（金属と思われる）が認 められた，歯髄処置は施されており，いずれも遠心 根に括いて歯根長の $2 / 3$ までにエックス線不透過像 （根管充填剂（材））が認められた。第三大臼歯は, 咬合面を一部覆うエックス線不透過像（金属と思わ れる）が認められ，また近心根抢よび遠心根の歯根 長の $1 / 2 \sim 1 / 3$ に及ぶエックス線不透過像（根管充 填剂（材）と思われる）が認められた。

【右側下顎側切歯一犬歯一第一 - 第二小臼歯】側 切歯と犬歯はう歯ではないが歯根長の $1 / 2 \sim 1 / 3$ 程 度の歯槽骨の垂直性骨吸収が著しく認められた。第 一小臼歯は歯冠部の一部を覆うようなエックス線不 透過像（金属と思われる）が認められた. 歯髄処置 は施されて抢り，歯根長の $1 / 4$ まで（根管充填材と 思われる)，またその部位から根尖方向 $1 / 2$ 屯で (根管充填剤と思われる)，さらには根尖方向 $3 / 4$ ま では螺旋形を呈するエックス線不透過像（根管治療 器具の一部）が認められた. 第二小臼歯では, 歯冠 部を全て覆うようなエックス線不透過像（金属と思 われる）が認められた，歯髄処置は施されていなか った。

\section{3）照合}

(1) 歯科所見（肉眼所見）

身元不明死体と該当者双方のデンタルチャートに 記載された歯科所見を比較・照合したところ，Fig.

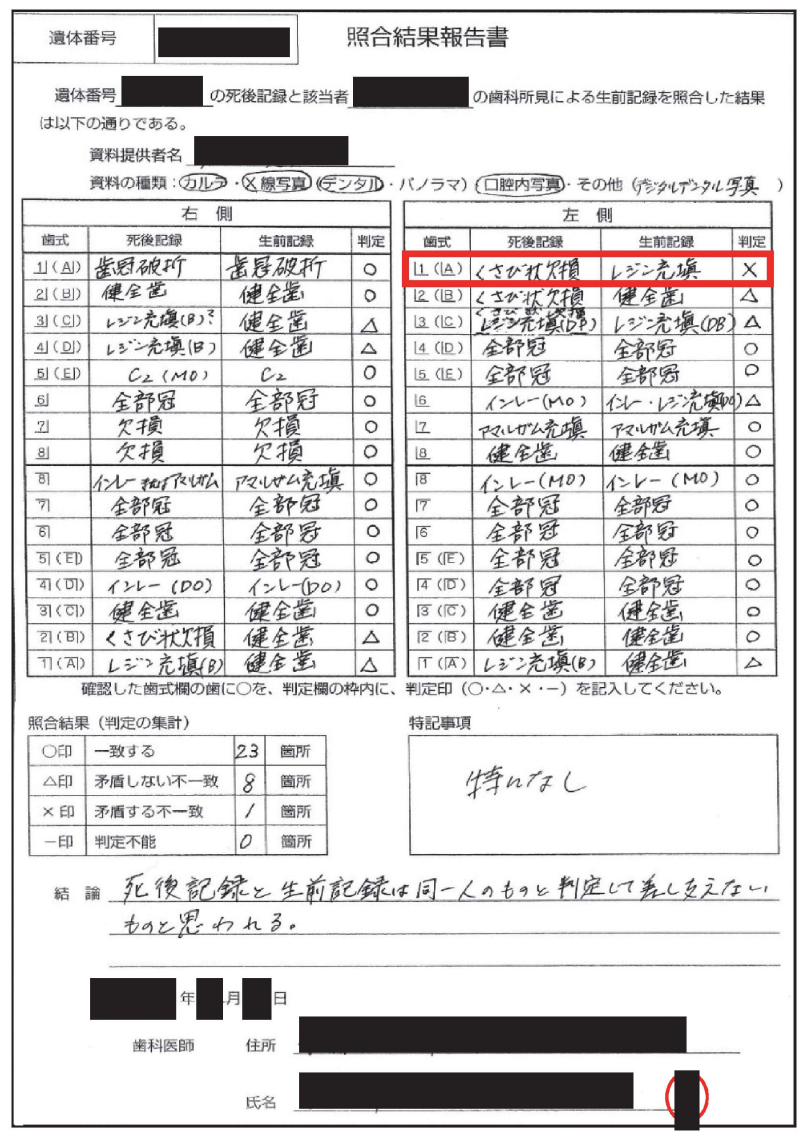

Fig. 4 Comparison and matching of the odontograms between the unidentified body and candidate individual.

4 に示すように，所見が一致している歯は23歯であ った。 また，所見は不一致ではあるが，歯科治療学 的に矛盾しない，すなわち生前所見よりも死後所見 の状態が進んでいる歯は 8 歯であった。一方, 左側 上顎中切歯について，死後所見は楔状欠損であるの に対して生前所見はレジン充填されており，不一致 かつ矛盾していた。

\section{(2) エックス線所見}

身元不明死体および該当者のデンタル写真を比 較・照合したところ，Table 1 に示すように，右側 下顎第一小臼歯に抢いて生前抢よび死後の歯冠修復 物の形態が類似しており，歯根中央部ではいずれも 遠心側へ弯曲し，その付近で根管充填剂の漏出が認 められた。また，根管充填剂の漏出に関連すると思 われる歯槽骨の吸収像が認められ，さらには近心壁 の垂直性の骨吸収像が歯根尖にまで達していた。ま 
Table 1 Comparison of intraoral radiographs between the unidentified body and candidate individual.

\begin{tabular}{|c|c|c|c|c|}
\hline & Unidentified body & Candidate individual & & Similarity \\
\hline $\begin{array}{l}\text { Rright } \\
\text { maxillary }\end{array}$ & & $\begin{array}{l}\text { Five years } \\
\text { before of death }\end{array}$ & 65 & $\begin{array}{l}\text { The radiopaque images of the full metal crown } \\
\text { and root canal filler in the palatal root are } \\
\text { similar. } \\
\text { The directions of eruption are similar. }\end{array}$ \\
\hline $\begin{array}{l}\text { Left } \\
\text { mandibular }\end{array}$ & & $\begin{array}{l}\text { Four months } \\
\text { before of death }\end{array}$ & $\begin{array}{l}\sqrt{8} \\
\sqrt{6} \\
678\end{array}$ & $\begin{array}{l}\text { The directions of eruption are similar. } \\
\text { The radiopaque images of the full metal crown } \\
\text { and root canal filler are similar. } \\
\text { The radiopaque images of the root canal filler } \\
\text { in the distal root are similar. } \\
\text { The root length is short in both and the direc- } \\
\text { tions of eruption are similar. }\end{array}$ \\
\hline $\begin{array}{l}\text { Right } \\
\text { mandibular }\end{array}$ & & $\begin{array}{l}\text { Four years } \\
\text { before of death }\end{array}$ & 4 & $\begin{array}{l}\text { The shape of coronal restorations is similar. } \\
\text { The degrees of the root curvature are similar. } \\
\text { There are perforations on the middle of the } \\
\text { roots at the distal wall. } \\
\text { Leakage of root canal filler from the perfora- } \\
\text { tion is observed. } \\
\text { The shapes of the abscess including the apex } \\
\text { caused by the leakage of root canal filler are } \\
\text { similar. } \\
\text { From the middle part of the root to the apex, a } \\
\text { remnant of a broken endodontic instrument } \\
\text { (approximately the size of a quarter of the } \\
\text { root) is observed in each image. }\end{array}$ \\
\hline
\end{tabular}

た，歯根中央部から歯根尖方向へ，歯根長 $1 / 4$ に及 ぶ根管治療器具の破折片が認められた。いずれの所 見も死後および生前においてよく類似していた。

\section{4）異同識別}

身元不明死体と該当者の歯科所見を検討した結 果，所見が一致拈よび不一致ではあるが歯科治療学 的に矛盾がない歯が31歯であり，矛盾していた 1 歯 についても充填されたレジンが脱落したと考えれ ば，死後の楔状欠損についても合理的な説明が成り 立つことから，同一人である可能性は非常に高いと 判断された.

また，右側下顎第一小臼歯のデンタル写真では， 歯根中央部の遠心側に抢いて根管充填剂の漏出に関 連すると思われる歯槽骨の吸収像，近心壁の歯根尖
付近にまで達する垂直性骨吸収像および歯根長 $1 / 4$ に及ぶ根管治療器具の破折片の不透過像が認められ た。それらの形態は類似性がきわめて高く，身元不 明死体と該当者は同一人であると判定した。

\section{考 察}

歯科診療録の歯型図には初診時の歯科所見を記入 することが一般的である。本事例において，歯科診 療録を提供した歯科医師に「情報なし」の歯につい て問い合わせをしたところ，「健全歯，う蝕や処置 などの施されていない歯の場合は何も記入していな い」旨の供述を得た. 日本歯科医師会発行の大規模 災害時の歯科医師会行動計画 改訂版 ${ }^{4)}$, 東京都福 祉保健局発行の㷋害時の歯科医療救護活動における 
身元確認班（歯科医師班）研修テキスト ${ }^{5}$ および日 本法歯科医学会ホームページの歯科所見の記載例6) によれば，健全歯，う蝕や処置などの施されていな い歯の場合は「健全歯」と表してよいとされており， 本事例においては供述を得たこともあり, 生前のデ ンタルチャート作成にあたり, 診療録の歯型図にお いて「情報なし」の歯については「健全歯」と記す こととし，所見の一致・不一致について検討するこ とにした。また，警察歯科医は死後所見の採取時 に，左側上顎前歯部は健全歯であったが楔状欠損が 認められたことからその旨を図示し，所見欄には 「くさび状欠損」と記入した. 以上のことから, 左 側上顎中切歯に抢ける死後と生前の所見が不一致か つ歯科治療学的に矛盾していたが，楔状欠損部に充 填されたレジンが脱落したと考えれば，この所見を もって同一人を積極的に否定することにはならない と思われた. むしろ, 他の31歯の所見が一致および 不一致ではあるが矛盾なしと判断できることのほう が同一人である可能性を高く示していると思われ た.

死後および生前における右側下顎第一小臼歯の工 ックス線画像を比較するとよく類似した所見を観る ことができる，すなわち，歯根中央部遠心壁におい て根管治療器具が穿孔したと思われる所見が，ま た，歯根中央部から歯根尖方向へ歯根長 $1 / 4$ ほどの 根管治療器具の破折片が認められた。歯根壁を穿孔 し，破折片を残置したままで根管充填が行われたこ とによって，糊剂が穿孔部から歯根膜腔へ漏出した ものと考えられる.さらには, 糊剂漏出に関連する と思われる歯槽骨吸収と, 上顎歯との咬合関係に関 連すると思われる歯根尖にまで達するほどの近心壁 の垂直性骨吸収が相まって, 重篤な根尖性歯周炎を 発症していた可能性がきわめて高いと思われた。な お, 根管治療器具の破折片については, エックス線 画像からではリーマーあるいはファイルのいずれか を識別することはできないものの，いずれもノンカ ッティングチップのピッチを数えることができるほ ど鮮明に観ることができる.

以上の所見は, 身元不明死体と該当者が同一人で あることを積極的に肯定し得る要因であると思われ た.
臨床上, 根管治療器具が一部破折し除去を試みる もやむを得ず残置せざるを得ない局面はどれほどで あろうか. 治療器具の破折について文献を検索する と $1 \%$ 未満から数十\%に及ぶものまで報告されてい る7,8)。わが国においては偶発症あるいは治療器具 の破折などとして紹介されている9-11)が，その頻度 にかかわる統計的な報告は見あたらない，臨床上に おける器具破折片残置の問題 ${ }^{22)}$ は別としても，破折 片の形態抒よび根管充填剂の漏出に関連すると思わ れる顎骨病変の所見が身元確認に有用であった事例 は珍しいと思われる。

\section{文 献}

1）警察庁刑事局鑑識課，第 1 章 歯科所見は, 身元確認になぜ有効か?, 警察庁刑事局鑑識課 (編)歯からの身元確認(鑑識執務資料第833号).

pp. 1-3, 警察庁, 東京, 1983.

2）古川 明, 伊澤 光, 丸山 澄, 小室歳信, 金属支台の形態ないしは適合性によって身元確 認された 2 事例. Forensic Dent. Sci., 6, 66, 2013.

3) 古川 明, 伊澤 光, 丸山澄, 堤 博文, 網干博文, 小室歳信, 根管治療器具破折片が有 力となり身元が確認された一事例. Forensic Dent. Sci., 8, 47-48, 2016.

4）公益社団法人日本歯科医師会 災害対策 · 警 察歯科総合検討会議, 用語, 略号の記載例, 公 益社団法人日本歯科医師会（編）大規模災害時 の歯科医師会行動計画 改訂版. 公益社団法人 日本歯科医師会, pp. 75-77, 東京, 2013.

5）東京都福祉保健局医療政策部救急災害医療 課，2 歯科記録用紙（生前記録・死後記録） の記入要領, 第 2 章 身元確認作業の実際, 災 害時の歯科医療救護活動に打ける身元確認班 （歯科医師班）研修テキスト，pp. 5-7, 東京都 福祉保健局, 東京, 2013.

6) 日本法歯科医学会, 歯科所見の記載例, available from [http: // www.jsfds.com / PDF / dentalchart.pdf], accessed Apr 13, 2018.

7) Mian, K. I., Meetu, R. K. and Jessica S. K., A retrospective clinical study of incidence of root 
canal instrument separation in an endodontics graduate program: APennEndo DatabaseStudy. Clin. Res., 32, 1048-1052, 2006.

8) Marc, G. F., Fernando, D. S., Sergio, M. C., Montserrat, M. B., Rufino, B. M. and Miguel, R. C., Failure of ProTaper rotary Ni-Ti instruments used by undergraduate students. J. Clin. Exp. Dent., 4, 199-203, 2012.

9）鈴木賢策，2. 根管内における器具の破折, 第15章 抜髄と根管治療時に起こる偶発事故, 鈴木賢策（編）明解歯内寮法学. pp. 237-239, 永末書店，東京，1981。

10）小木曽文内，林 誠，歯内療法に打ける最近 のトピックス. 東京都歯科医師会雑誌，60, 310, 2012.

11）武市 収, 林 誠, 小木曽文内, 偶発症由来
の難治性根尖性歯周炎の診断と治療一治りにく い根管治療の患者さんが来院したら一。東京都 歯科医師会雑誌, 63, 3-10, 2015.

12）株式会社 TKC，LEX/DBインターネット TKC 法律情報データベース，平成22年（ワ）第 38408号 損害賠償請求事件 東京地方裁判所, 原告が，被告の開設する歯科クリニックにおい て, 被告から右上 4 番に対する根管治療を受け たところ，被告が治療用リーマーを破折させ， 根管内に残置させたなどとして，被告に対し， 債務不履行に基づき損害の賠償を求めた事案に おいて, 請求を棄却した事例, available from [http://lex.lawlibrary.jp/lexbin/SearchAllResult. aspx $? \mathrm{ik}=636668275480833644 \& \mathrm{isc}=20$ \&iso $=$ 0\&isk $=1 \&$ pi $=1]$, accessed Apr 13, 2018. 